\title{
Two cases of ring chromosome 11
}

\author{
D R ROMAIN*, O B GEBBIE*, R G PARFITT*, \\ L M COLUMBANO-GREEN*, R H SMYTHE*, C J CHAPMAN†, \\ AND A KERR+
}

From * the Cytogenetic Laboratory, Laboratory Services, Wellington Hospital, and $\dagger$ Wellington Clinical School of Medicine; and $\ddagger$ the Paediatric Department, Hutt Hospital, Wellington, New Zealand.

SUMmaRY Two cases of ring chromosome 11 are reported. Both had mental retardation, micro- î cephaly, and short stature. High resolution $\mathrm{G}$ banding in case 1 showed no visible loss of chromatin, ir the karyotype being assessed as 46,XX,r(11) (p15.4q2.5). In case 2, a Wilms's tumour developed at $\dot{\infty}_{\infty}$ 8 months and the child died at 18 months. Cytogenetic analysis by $\mathrm{Q}$ banding demonstrated minimal chromosome deletion and the karyotype was considered to be 46,XY,r(11) (p15q25).

Reports of ring chromosome 11 are rare. ${ }^{1-4}$ In our case 1 , high resolution banding showed no visible loss of chromatin. Similarly, all other reported cases, including case 2 of this paper, had breakpoints at p15 and q25. Other than in the reports by Niikawa et $a l^{3}$ and Scott-Emuakpor et $a l^{4}$ no great overlap with the 11q- syndrome was noted. A search of published reports revealed no cases of terminal deletion $11 \mathrm{p}$ for comparison studies.

\section{Case reports}

CASE 1

This was the first of two duaghters born to parents of European origin. Pregnancy went to term with no complications and birth weight was $2 \cdot 2 \mathrm{~kg}$. There were no other unusual findings other than slight antimongoloid slant of the eyes. At 9 months her height was $61.5 \mathrm{~cm}, 3 \mathrm{SD}$ below the $3 \mathrm{rd}$ centile, and weight was $6.4 \mathrm{~kg}, 2$ SD below the $3 \mathrm{rd}$ centile. She was found to have a geographic tongue.

At 15 months she gave a history suggesting normal psychomotor development: she could walk at 1 year and use six or more single words with meaning.

At 32 months the patient was referred for behavioural and speech problems. At 46 months the head circumference was $45 \mathrm{~cm}$, height $86.4 \mathrm{~cm}$, and weight $12.0 \mathrm{~kg}$. Physical examination revealed no heart murmur. A café-au-lait mark was noted on the lower abdomen. Her speech was mostly unintelligible, although she understood commands without problem. At 49 months she had an overall mental age of 43 months. At the present age of 54 months her speech is slowly improving but her height and weight are below the 3rd centile. The patient's sister is phenotypically normal.

\section{CASE 2}

This was a male child of a mother known to have taken LSD before pregnancy and marijuana during pregnancy. The pregnancy went to term with no complications, and birth weight was $2.3 \mathrm{~kg}$, crown $\Phi$ to heel length was $45 \mathrm{~cm}$, and head circumference was $\vec{\Rightarrow}$ $31 \mathrm{~cm}$. Facies, palate, heart, and external genitalia 윽 were all normal. There was syndactyly of the left foot (fused third and fourth digits). At 8 months mental development was equal to 3 months and he developed a Wilms's tumour. The patient died at 18 months.

\section{Cytogenetic investigations}

CASE 1

Chromosome analysis was done on PHA stimulated $D$ heparinised venous blood cultures. One hundred cells were examined by routine GTG banding and by $N$ high resolution banding. The karyotype was assessed as $46, \mathrm{XX}, \mathrm{r}(11)(\mathrm{p} 15.5 \mathrm{q} 25)$. Of these cells, $8 \%$ showed a loss of the ring, $4 \%$ contained a dicentric $\omega$ ring, and $2 \%$ showed dicentric rods (figs 1,2 , and 3 ). The parents' chromosomes were normal.

\section{CASE 2}

Chromosome investigations were done on both PHA stimulated heparinised venous blood cultures $\underset{\mathbb{D}}{\vec{D}}$ and skin fibroblast cultures. One hundred cells were $\stackrel{?}{\mathbb{P}}$ analysed from the blood cultures by conventional $\cong$ 


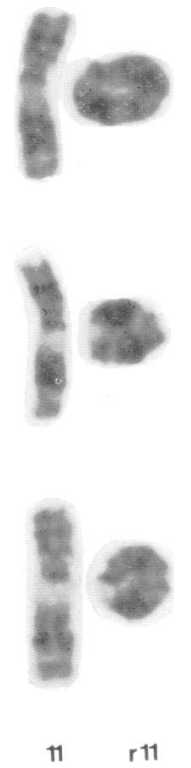

FIG 1 GTG banded examples of $r(11)$ from case 1 .

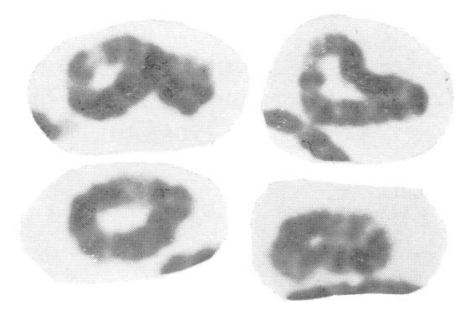

p

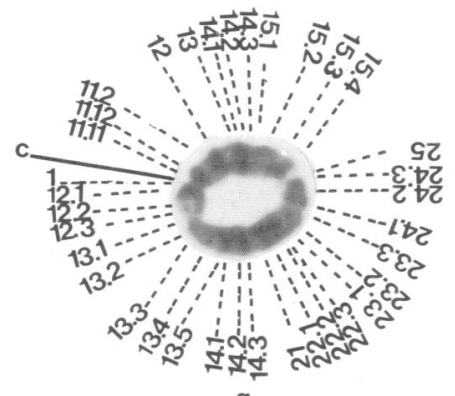

q

FIG 2 High resolution $G$ banded examples of $r(11)$ in mid-prophase from case 1 .

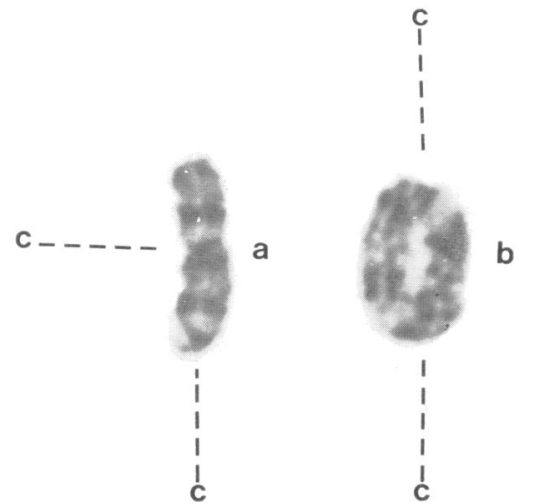

FIG 3 (a) Example of rod and (b) dicentric r(11) from case $1 ;(c)$ denotes centromeres.

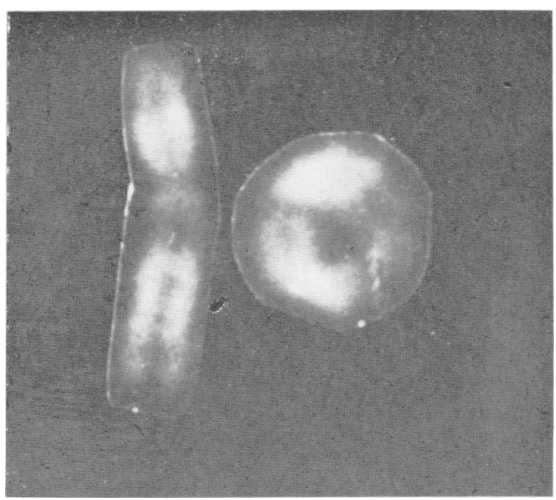

FIG $4 \quad Q F Q$ banded $r(11)$ from case 2.

staining and QFQ banding. Of these cells, 6\% showed loss of the ring and $2 \%$ contained a dicentric ring. No rod forms were seen. Twenty cells were examined from the fibroblast cultures with the ring present in every cell (fig 4; derived from photographic record prepared in 1971/2). The karyotype was assessed as 46,XY,r(11)(p15q25). Maternal chromosome analysis was normal.

\section{Discussion}

The majority of cases of ring chromosomes have in common mental retardation, small stature, and microcephaly. The diversity of clinical features, however, prevents in the main the delineation of distinctive syndromes, although there are now enough reports associated with $r(X), r(1), r(6), r(9)$, $r(13), r(18), r(21)$, and $r(22)$ to show comparable clinical manifestations. 
The structural and behavioural instability of ring chromosomes is well documented. It is sufficient to say that ring chromosome phenotypes can be related to mosaicism and aneuploidy as well as chromosome deletion. Even with high resolution banding, it is not possible to demonstrate with certainty complete retention of chromatin in a ring, unless end-to-end telomeric fusion is proposed as an alternative explanation for ring chromosome formation..$^{5-8}$ of the $\mathrm{r}(11)$ cases reported, all had mental retardation, café-au-lait spots, short stature, and microcephaly.

There is great similarity between our case 1 and that of Valente et al, ${ }^{1}$ both showing additional speech and behavioural problems. The case of Retbi et $a l^{2}$ showed hypertelorism, digital anomaly, and systolic murmur.

The cases of Niikawa $e t a l^{3}$ and Scott-Emuakpor et $a l^{4}$ show considerable overlap with the $11 \mathrm{q}-$ syndrome and, as indicated by the authors, this could be explained by an increased loss of chromatin material in the formation of the ring chromosome or a greater proportion of missing or rearranged rings during mitosis or both. In both of our cases, we suggest the clinical abnormalities may be attributable to the ring chromosome instability rather than to chromosomal deletion.

In case 2 there was development of a Wilms's tumour which was possibly associated with the r(11). There was no history of aniridia and, although high resolution banding was not performed, there appeared to be no loss of chromatin from bands p13 $\rightarrow$ p14.

We thank Drs A McDermott and F J M Lewis, and Mr R H Poulding of the Southwest Regional
Cytogenetic Centre, Southmead Hospital, Bristol, $\stackrel{\mathbb{P}}{=}$ for permission to publish case 2 . We thank Mrs $M \vec{\Rightarrow}$ Willis for typing the manuscript and the Audiovisual Aids Department, Wellington Clinical School of Medicine, for assistance with the illustrations.

\section{References}

1 Valente M, Muller H, Sparkes RS. Ring 11 chromosome $\vec{\circ}$ [46,XX,r(11)(p15q25)]. Hum Genet 1977;36:345-50.

2 Retbi JM, Raoul D, Allemon MC, Dayras JC. Chromo- $\vec{\omega}$ some 11 en anneau [46,XX,r(11)]. Une nouvelle observation. Nouv Presse Med $1981 ; 10: 181$.

3 Niikawa N, Jinno Y, Tomiyasu $T$, Fukushima $Y, \stackrel{\oplus}{0}$ Kudo K. Ring chromosome 11 [46,XX,r(11)(p15q25)]. N Associated with clinical features of the 11q- syndrome. ir Ann Genet (Paris) 1981 ;24:172-5.

4 Scott-Emuakpor AB, Cousineau AJ, Higgins J, Mody G. Ring chromosome 11: phenotype-karyotype correlation with the 11q-syndrome. Am J Hum Genet $1981 ; 33: 121$ A. S

5 Cavalier-Smith T. Palindromic base sequences and replication of eukaryote chromosome ends. Nature 1974; 250:457-70.

- Dutrillaux B, Aurias A, Couturier J, Croquette MF, 음 Viegas-Pequignot E. Multiple telomeric fusions and chain $\mathbb{D}$ configurations in human somatic chromosomes. Chromosomes Today 1977;6:37-44.

7 Fraisse J, Laurent C, Collard N, Biemont MC, Dutrillaux B. Un deuxième exemple de fusion télomérique de deux chromosomes X. Ann Genet (Paris) 1975;18: 243-5.

8 Distèche C, Hagemaijer A, Frederic J, Progneaux D. An abnormal large human chromosome identified as an endto-end fusion of two X's by combined results of the new

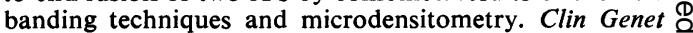
$1972 ; 3: 388-95$.

Correspondence and requests for reprints to Mr D R Romain, Cytogenetic Laboratory, Laboratory Services, Wellington Hospital, Wellington 2, New Zealand. 